\title{
LIFE CYCLE AND ECOLOGY OF MAYFLIES FROM SIERRA NEVADA (SPAIN), IV
}

\section{J. Alba-Tercedor}

Departamento de Biología Animal, Ecología y Genética, Facultad de Ciencias, Universidad de Granada. 18071-Granada, Spain.

Keywords: autoecology, life cycles, Ephemeroptera, Sierra Nevada, Spain.

\begin{abstract}
The life cycle, distribution and autoecology of Ephemerella ignita (PoDA, 1761), Ephemera danica Múcler, 1764, Caenis luctuosa BurmeIsTer, 1839, Epeorus sylvicola (PICTET, 1865) and $\boldsymbol{E}$. torrentium EATON, 1881 are presented as a result of monthly samples taken from six streams in the Sierra Nevada mountains (southern Spain).
\end{abstract}

\section{INTRODUCTION}

This study is part of another in which the autoecology and life cycles of mayflies from the Sierra Nevada mountains (Southern Spain) were studied. This was presented as a doctoral thesis (ALBA-TERCEDOR, 1981) and some of these results have been published (ALBA-TERCEDOR, 1983,1986 and 1990).

\section{MATERIALS AND METHODS}

Eight sampling stations were distributed in five streams on both the northern and southern slopes of the Sierra Nevada (Río Aguas Blancas: 1300 m, 1140 m, 800 m; Río Dúrcal: 760 m; Río Torrente: 840 m; Río Lanjarón: 640 m; Río Chico: 800 m; and Río Poqueira: $1600 \mathrm{~m}$; respectively numbered I to VIII).

Samples were taken monthly (from April 1979 to March 1980) from both banks and from central zones, using a Surber sampler (mesh size $0.36 \mathrm{~mm}$ and sampling surface $0.07 \mathrm{~m}^{2}$ ). Type of bed was noted and current velocities at the bottom were reg-

Limnetica, 6: 23-34 (1990)

(C) Asociación Española de Limnología, Madrid, Spain istered with an instrument similar to that described by DowDESwELL (1967). The chemical characteristics and temperature of the water were analysed and measured as explained more extensively in previous papers (AlBA-TERCEDOR, 1983).

For the study of life cycles the total length of specimens (without cerci) was measured using an ocular scale with $0.1 \mathrm{~mm}$ accuracy and for Epeorus nymphs, development stages were distinguished in accordance with AlBA-TERCEDOR $(1981,1983)$. Monthly frequency histograms were produced (figs. 1-8), based on the data obtained.

\section{RESULTS}

\section{Ephemerella ignita (PoDA, 1761)}

Nymphs were collected at every sampling station. The most numerous populations were observed at stations II and III (average of nymphs/ $\mathrm{m}^{2}: 180$ and 141 respectively).

The nymphs are more frequent in zones near the banks, with abundant vegetation, zones with a depth between $4-40 \mathrm{~cm}$, with currents at the bottom ranging from very slow $(<0.1 \mathrm{~cm} / \mathrm{s}-\mathrm{im}-$ possible to measure with the instrument used-) to moderately fast (108 \pm 9 cmís), and different 
substrata (sandy bottoms with a thin layer of mud or stony and pebble substrata), in accordance with previous observations (e.g.: BASS, 1976; ELLIOTT, 1978; GRANDI, 1960; JAZDZEWSKA，1971; Macan, 1970, 1979; SANDER, 1981; Sowa, 1975a; etc...).

Numerous studies on the life cycle of this species have been reported (see Clifford, 1982). In order to study the life cycle in Sierra Nevada, histograms were drawn, based on the study of 83 ,
$380,356,30,28,23$ and 10 nymphs caught at sampling stations I-IV and VI-VI11 (figs.: 1-3).

According to our results, this species appears to be univoltine with a emergence period between late June and September. At higher water temperatures, hatching was sometimes delayed (e.g. sampling stations VI and VII with summer temperatures higher than $20^{\circ} \mathrm{C}$ ). However at other stations (e.g. II and IV) small nymphs were collected from February onwards.

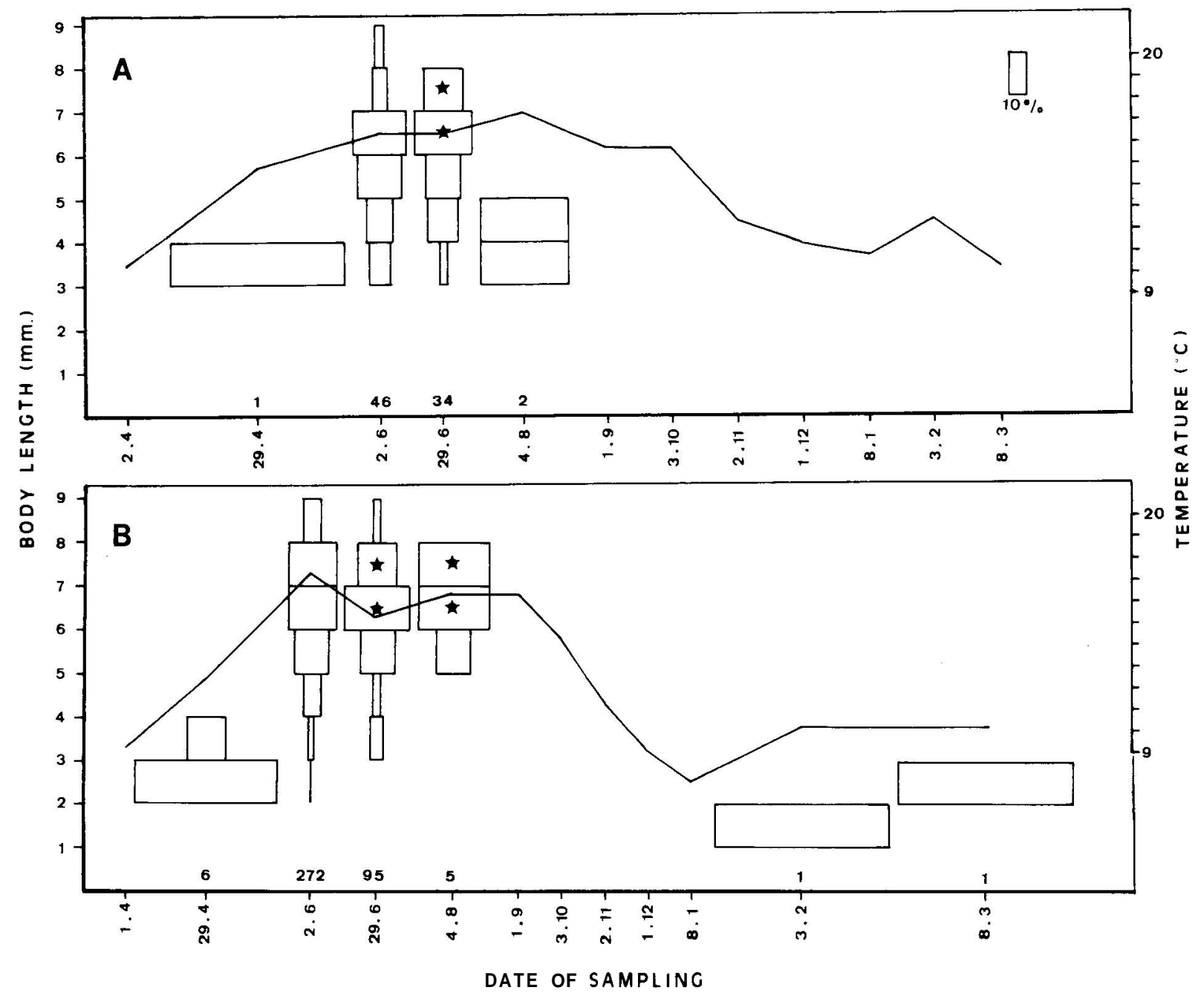

Figure 1.- Life-cycle data for Ephemerella ignita from Río Aguas Blancas: A) 1300 m, B) 1140 m. Asterisks indicate the presence of mature nymphs with black wing pads. Monthly evolution of water temperature is represented by a solid line. The number of nymphs caught every month is indicated.

Datos sobre el ciclo de vida de Ephemerella ignito del Río Aguas Blancas: A) 1300 m, B) 1140 m. Los asteriscos indican la presencia de ninfas maduras con los estuches alares negros. La evolución mensual de la temperatura se representa por una línea continua. Se indica el número de ninfas capturadas cada mes. 
Ephemera danica (MÜLleR, 1764)

During the study, this species was found only in the stream Río Aguas Blancas (sampling stations I and III) which has harder water compared to other sampling stations $(145-470 \mu \mathrm{S} / \mathrm{cm}-$ mean: $395.6 \mu \mathrm{S} / \mathrm{cm}$ ). The highest populations were found in the upper part of this stream, with densities of 250.3 and 267 nymphs $/ \mathrm{m}^{2}$ for sampling stations I and II respectively (only two nypmhs were caught at station III). The preferential distribution of this species in the upper part of streams had been reported earlier (e.g.: Alba-Tercedor \& JiMÉnEZMillán, 1978; Whelan, 1980).

The nymphs are more frequently found in the banks (4-17 cm depth), in sandy-muddy beds with vegetation and debris (this agrees with MACAN, 1970, 1979; WISE, 1976; Whelan, 1980 and SAN. DER, 1981). Current velocities of the zones inhabited by this species were variable, from very slow $(<0.1 \mathrm{~cm} / \mathrm{s}-$ impossible to measure with the

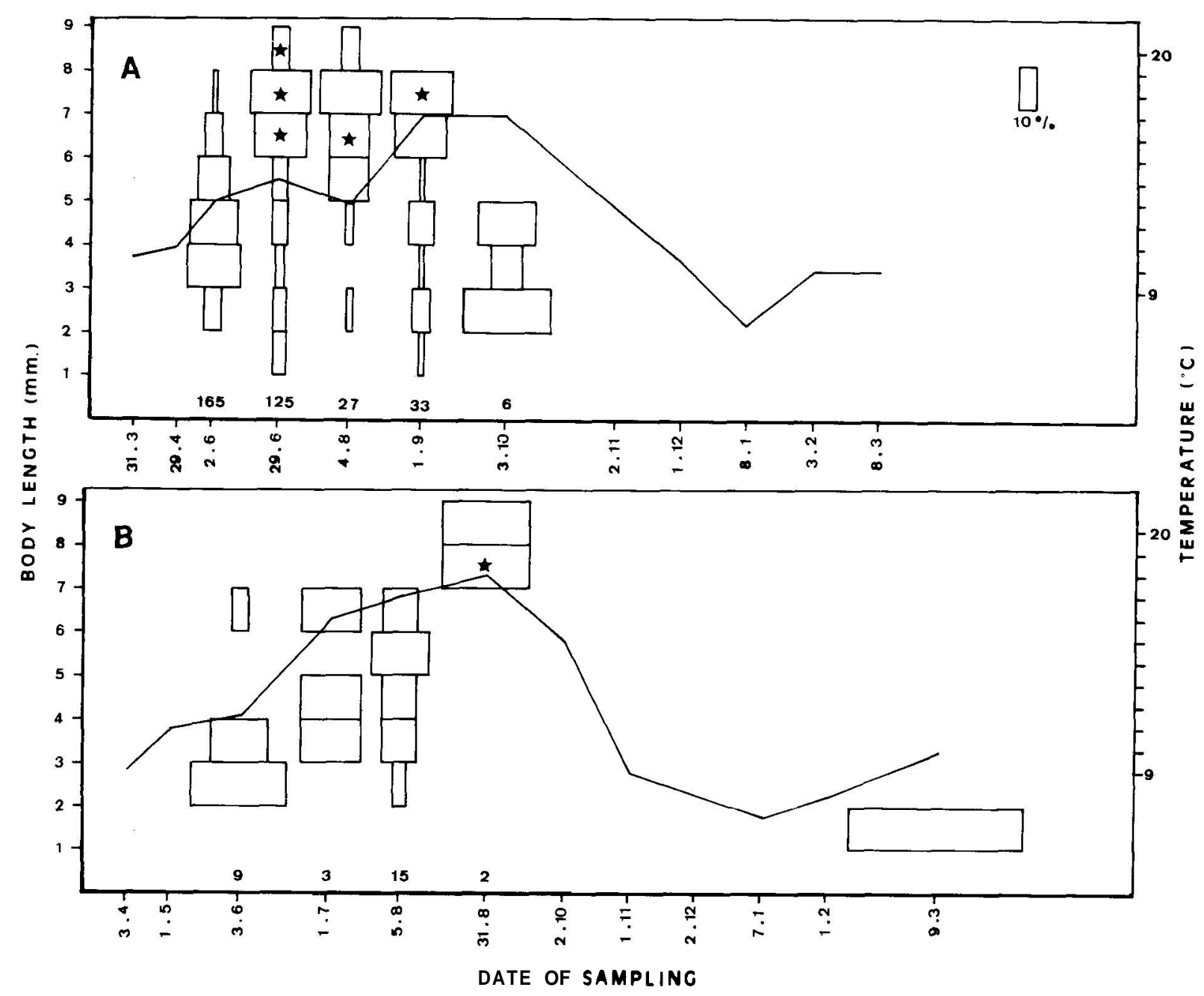

Figure 2.- Life-cycle data for Ephemerella ignita from: A) Río Aguas Blancas, $800 \mathrm{~m}$, B) Río Dúrcal, 760 m. Astensks indicate the presence of mature nymphs with black wing pads. Monthly evolution of water temperature is represented by a solid line. The number of nymphs caught every month is indicated.

Datos sobre el ciclo de vida de Ephemerella ignita de A) Río Aguas Blancas, $800 \mathrm{~m}$, B) Río Dúrcal, $760 \mathrm{~m}$. Los asteriscos indican la presencia de ninfas maduras con los estuches alares negros. La evolución mensual de la temperatura se representa por una línea continua. Se indica el número de ninfas capturadas cada mes. 

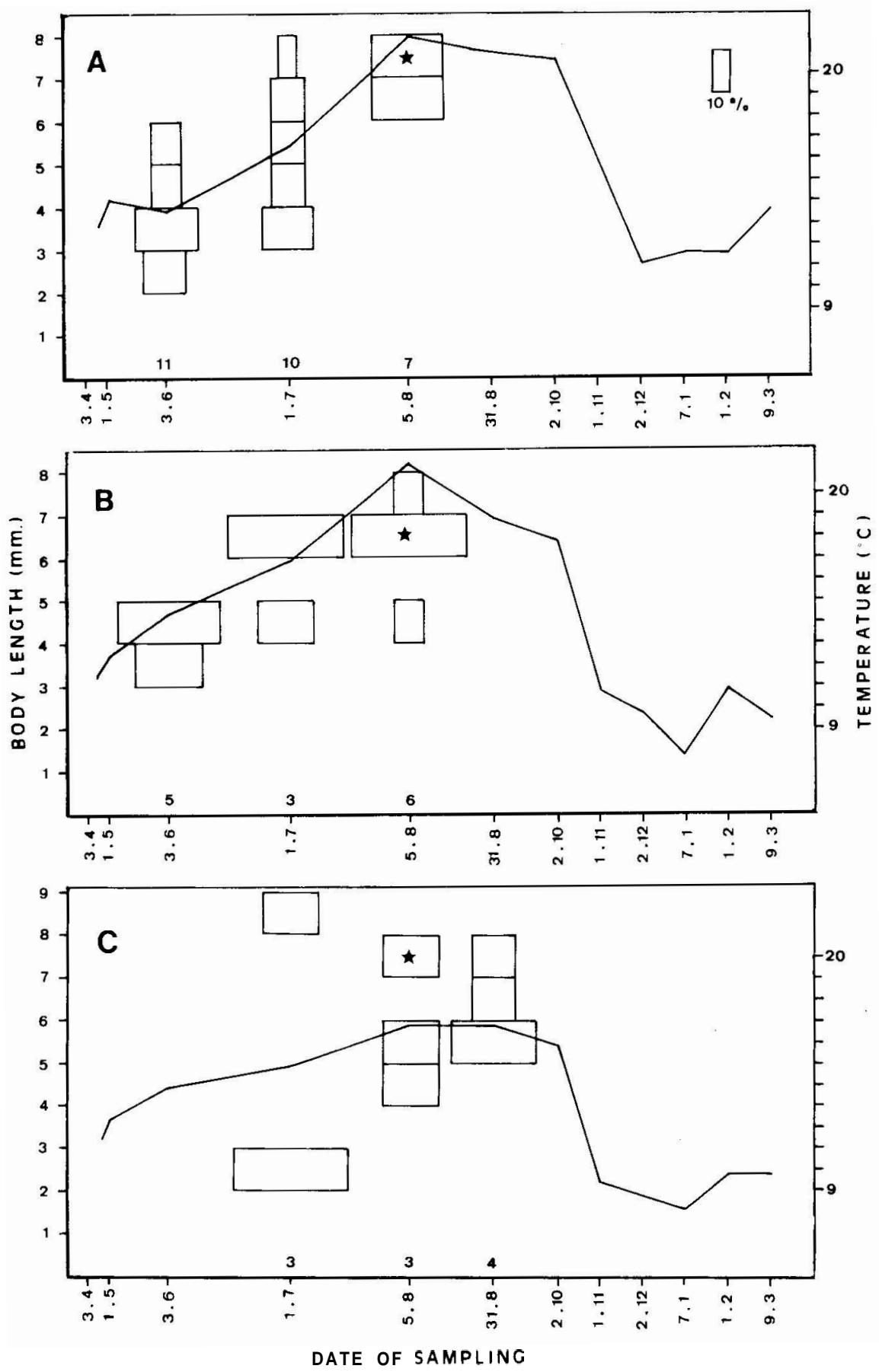

Figure 3.- Life cycle data for Ephemerella ignita from A) Río Lanjarón, 640 m, B) Río Chico, 800 m, C) Río Poqueira, 1600 m. Astensks indicate the presence of mature nymphs with black wing pads. Monthly evolution of water temperature is represented by a solid line. The number of nymphs caught every month is indicated.

Datos sobre el ciclo de vida de Ephemerella ignita: A) Río Lanjarón, 640 m, B) Río Chico, 800 m, C) Río Poqueira, 1600 m. Los astenscos indican la presencia de ninfas maduras con los estuches alares negros. La evolución mensual de la temperatura se representa por una línea continua. Se indica el número de ninfas capturadas cada mes. 
instrument used-) to moderate $(88 \pm 6 \mathrm{~cm} / \mathrm{s}$ ) (on one occasion 38 nymphs were caught in a zone with abundant small roots of vegetation from the banks and with a current velocity of $109 \pm 9$ $\mathrm{cm} / \mathrm{s})$.

The life cycle was similar at every sampling station where nymphs were caught, and for this reason the graph presented (fig. 4) is based on the measurements of 969 nymphs from stations I and II.

The emergence' of subimagines occurred from June to the first half of August. The hatching of the eggs started at the beginning of October (four months after the first emergence of subimagines). After this, new hatching occurred at intervals from the beginning of February.

\section{Epeorus sylvicola (PICTET, 1865) and E. torrentium} (EATON, 1881)

Nymphs of genus Epeorus were caught at sampling stations I, II and IV-VIII. At present it is not possible to distinguish between the nymphs of the two species (Berthelemy \& Thomas, 1967; AlBA-TERCEDOR, 1981), and for this reason, both species are considered together. Nevertheless, adults of $\boldsymbol{E}$. sylvicola were caught in Río Aguas

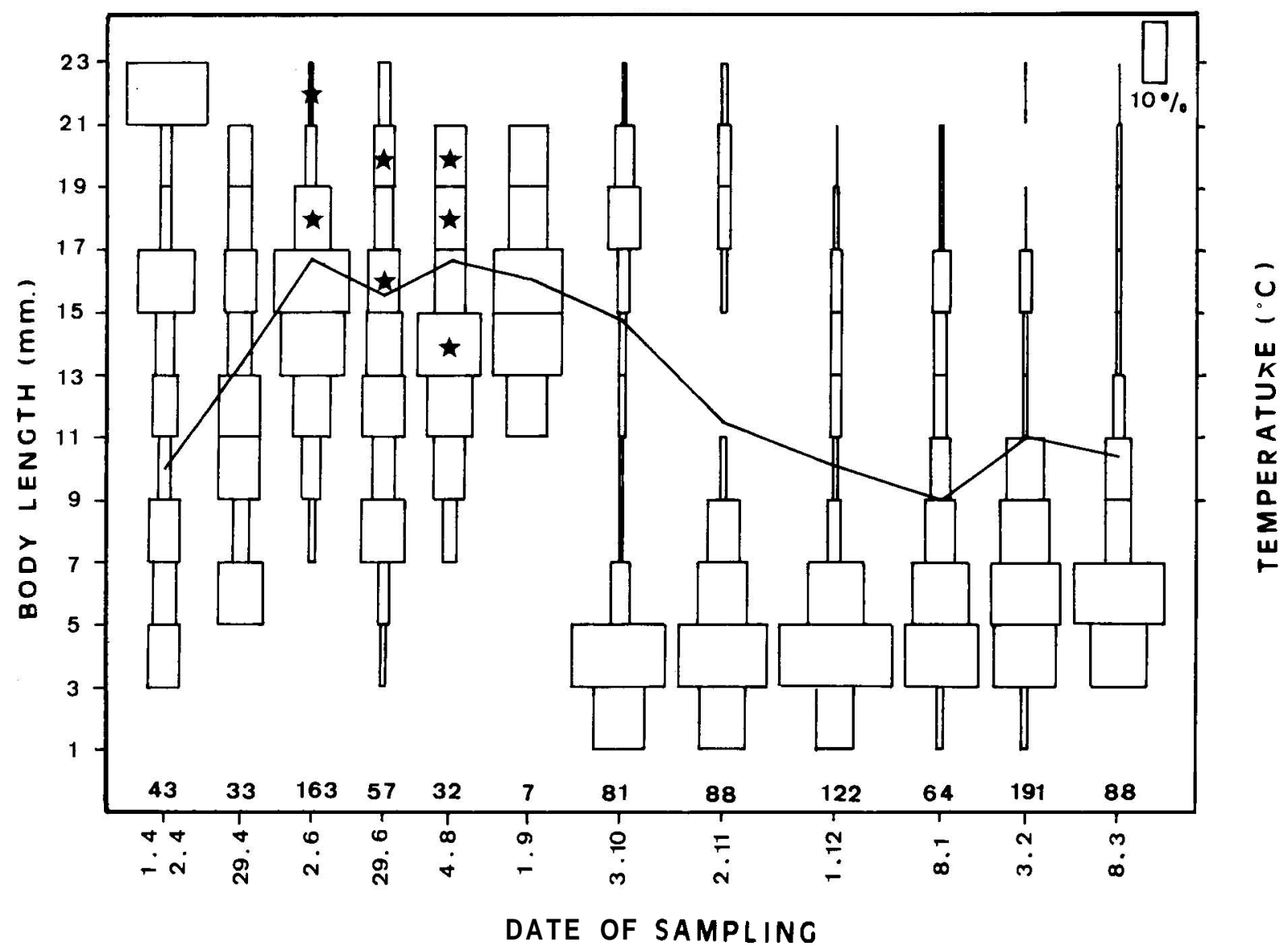

Figure 4.- Life-cycle data for Ephemera danica from Río Aguas Blancas (1300 m and $1140 \mathrm{~m})$. Astensks indicate the presence of mature nymphs with black wing pads. Monthly evolution of water temperature is represented by a solid line. Number of nymphs caught every month is indicated.

Datos sobre el ciclo de vida de Ephemera danica del Río Aguas Blancas $(1300 \mathrm{~m}$ y $1140 \mathrm{~m})$. Los astenscos indican la presencia de ninfas maduras con los estuches alares negros. La evolución mensual de la temperatura se representa por una línea continua. Se indica el número de ninfas capturadas cada mes. 
Blancas and Río Poqueira; while E. torrentium was only caught in Río Aguas Blancas.

The nymphs occur preferentially in central zones on stony substrata with current velocities of between $45 \pm 8 \mathrm{~cm} / \mathrm{s}$ and $121 \pm 11 \mathrm{~cm} / \mathrm{s}$, but generally higher than $60 \mathrm{~cm} / \mathrm{s}$. This agrees with the observations of DoRIER \& VAILlant (1954) who reported E. sylvicola (subnom. E. assimilis) inhabiting a maximum current speed of $109 \mathrm{~cm} / \mathrm{s}$ and going upstream against current velocities of $230 \mathrm{~cm} / \mathrm{s}$.

In order to study the life cycle, histograms based on the study of $80,35,17,53,67$ and 115 nypmhs were produced for sampling stations I, II, IV and VI-VI11 respectively (figs. 5-7). Moreover data assembled from sampling stations 1-11 and VI-VI11 are shown (fig. 8).
Both species appear to be univoltine, with a similar development to that proposed by LANDA (1968) for E. sylvicola (subnom. E. assimilis Etn.).

\section{DICUSSION}

\section{Ephemerella ignita (PoDA, 1761)}

The results of the influence of temperature on hatching time of eggs agrees with the results and studies of JeNSEN (1956), Thibault $(1969,1971)$, Bass (1976), Bohle (1972), Elliott (1978), JAZDZEWSKA (1980).

In most sampling stations the growth was uniform, but in some (e.g. station III) two hatchings were observed during the summer: one in late July

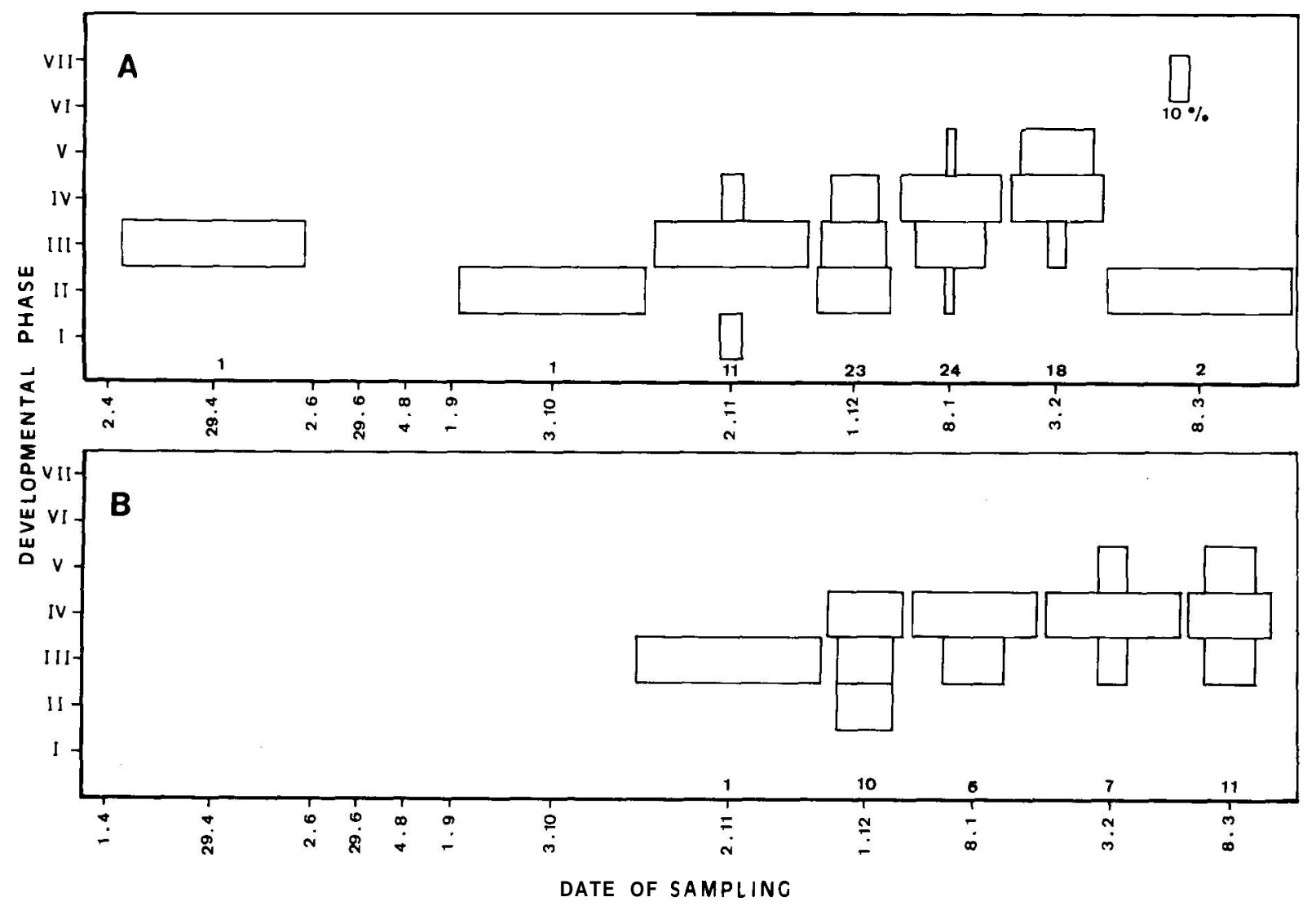

Figure 5.- Life-cycle data for Epeorus sylvicola/E. torrentium (see text) from Río Aguas Blancas: A) $1300 \mathrm{~m}$, B) $1140 \mathrm{~m}$. The number of nymphs caught every month is indicated.

Datos sobre el ciclo de vida de Epeorus sylvicola/E. torrentium (ver texto) del Río Aguas Blancas: A) 1300 m, B) $1140 \mathrm{~m}$. Se indica el número de ninfas capturadas cada mes. 
and the other at the beginning of September (fig. 2 A). The first may correspond to eggs from the previous year delayed in hatching, the second hatching could be explained in the same way; but considering the fact that it occurs two months after the first emergence of subimagines, it could indicate that these nymphs correspond to the beginning of a second generation. This hypothesis fits in well with results of Thibault and Elliott because, considering the water temperatures at this sampling station, hatching may have occurred after an incubation period of two months. A second generation would explain the presence of small and halfgrown nymphs during October; however these nymphs did not survive the winter. Therefore our results would confirm the presence of a failed 2 nd generation suggested by other authors (PLESKOT, 1959; Hynes, 1961; ElliotT, 1967, 1978; Wise, 1980; Rosillon, 1986).

\section{Ephemera danica (MÜLlER, 1764)}

The life cycle of this species has been studied by different authors (see Clifford, 1982) and different results were obtained. Some concluded that E. danica is an univoltine species (e.g.: Pleskot, 1959, 1961 in Austria; PeArt, 1916 in England; JAZDZEWSKA, 1971 in Poland, and suggested in France by ThIBAUlt, 1971); however other authors consider this a semivoltine species with a two-year development period (e.g.: LANDA, 1968 in Czechoslovakia; GuILlouzIC, 1965 and Thibault, 1971 in France; Halford, 1889; PerCIVAL \& WhiteHEAD, 1928 and Wright et al., 1981 in England; SowA, 1975 a, 1975b in Poland), or with a three-year development period (e.g.: ILLIES, 1952 in Germany; Wright et al., 1981 in England). Moreover, in accordance with different factors, 1-2 year (WHELAN, 1980 in Ireland) and

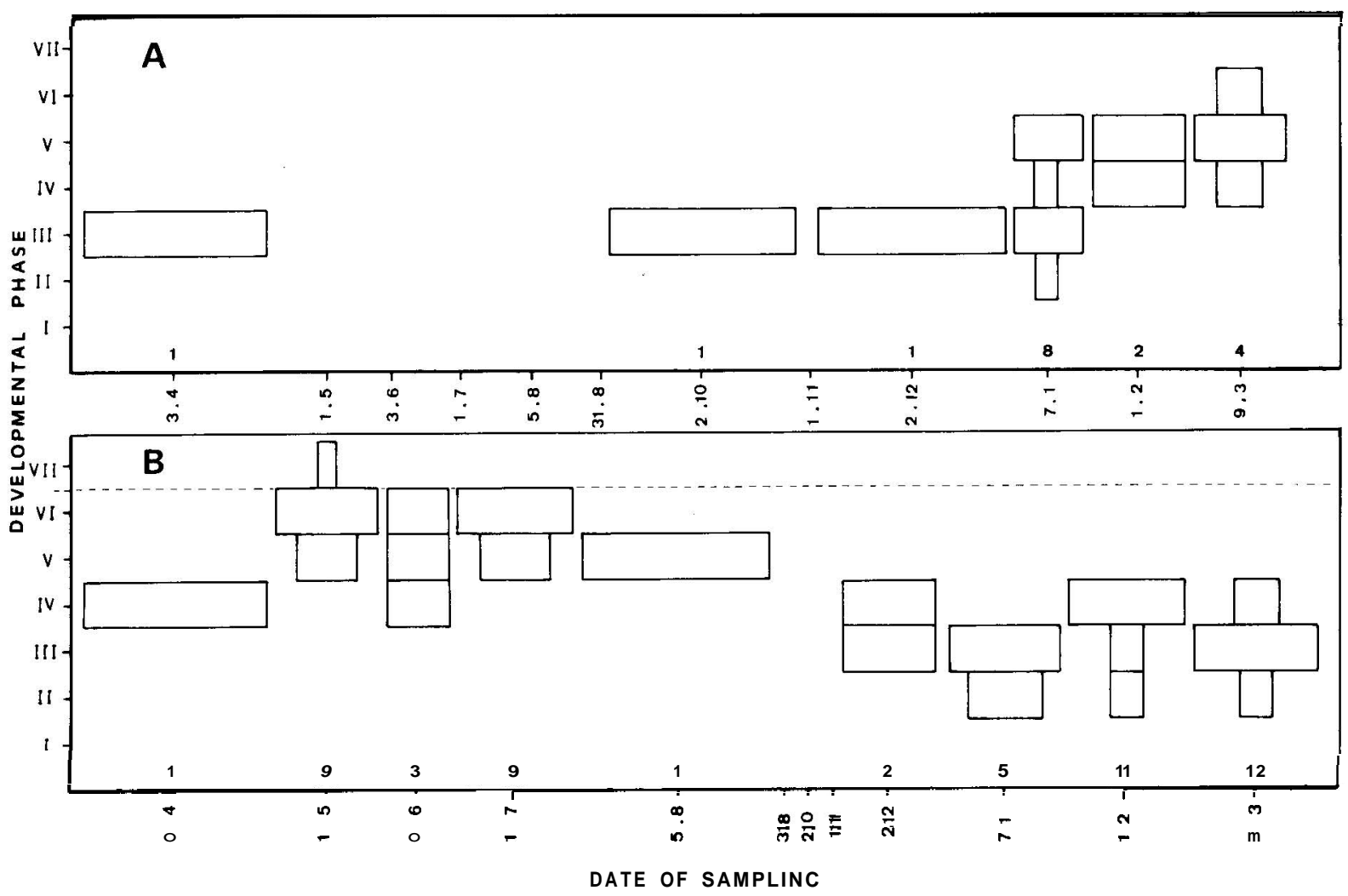

Figure 6.- Life-cycle data for Epeorus sylvicola/E. torrentium (see text): A) from Río Dúrcal, 760 m, B) from Río Lanjarón, 640 $\mathrm{m}$. The number of nymphs caught every month is indicated.

Datos sobre el ciclo de vida Epeorus sylvicola/E. torrentium (ver texto): A) Río Dúrcal, $760 \mathrm{~m}$, B) Río Lanjarón, $640 \mathrm{~m}$. Se indica el número de ninfas capturadas cada mes. 
2-3 year (Svensson, 1977 in Sweden) development periods have been described.

On the other hand Delvaux (1979), in Luxemburg, studying the influence of the parasitic Spiriopsis adipophila, found either one, two or three year cycles depending on the degree of infection.

In Sierra Nevada it is interesting to note the following: a) the presence of small nymphs together with grown ones was apparent from the beginning of October to December and even until FebruaryMarch; b) the growth of nymphs hatched in summer was slow during summer and winter but accelerated at the beginning of March and during spring; c) independently of sex, fully-grown nymphs caught at the beginning of the emergence period were clearly longer than those caught at the end.
Therefore we conclude that part of the population has a semivoltine cycle (grows for two years) while the other has a univoltine cycle.

The first fully-grown nymphs would correspond to a semivoltine population which are consequently longer (because their development time was longer) than later fully-grown nymphs which would correspond to the univoltine population.

Epeorus sylvicola (РICTET, 1865) and E. torrentium (EATON, 1881)

Studies on these species carried out in different parts of Europe postulated for E. sylvicola an univoltine winter cycle and for $\boldsymbol{E}$. torrentium a bivoltine winter-summer cycle (see Clifford, 1982). Even Thibault (1971) in Southern France con-

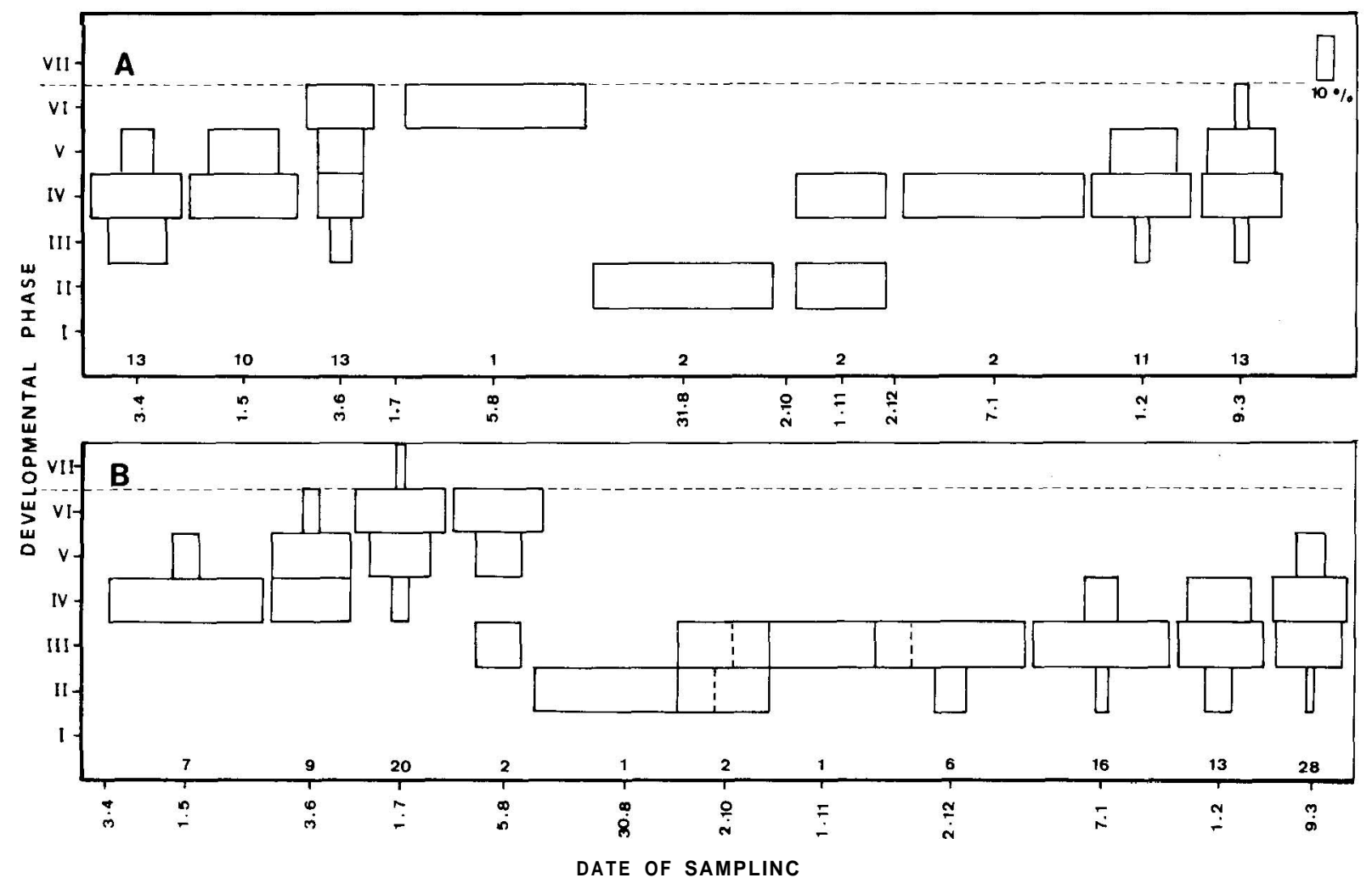

Figure 7.- Life-cycle data for Epeorus sylvicolal E. torrentium (see text): A) from Río Chico, 800 m, B) from Río Poqueira, 1600 $\mathrm{m}$. The number of nymphs caught every month is indicated.

Datos sobre el ciclo de vida de Epeorus sylvicola/E. torrentium (ver texto): A) Río Chico, 800 m, B) Río Poqueira, 1600 m. Se indica el número de ninfas capturadas cada mes. 


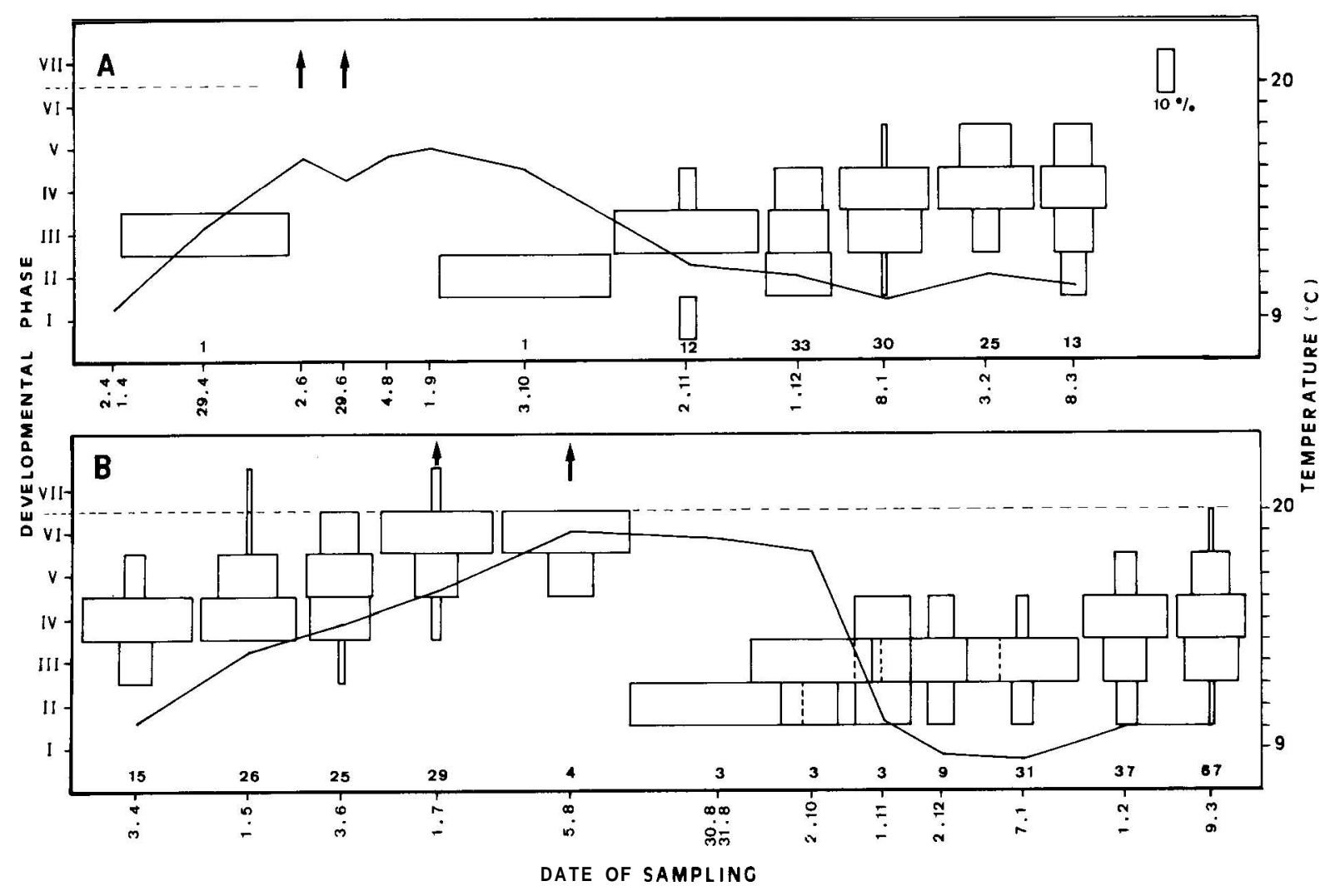

Figure 8.- Life-cycle data for Epeorus sylvicola/E. torrentium (see text): A) Assembled data of sampling stations from Río Aguas Blancas, B) assembled data of sampling stations IV-VIII. Arrows indicate captures of adults. Average of monthly evolution of water temperature is represented by a solid line. The number of nymphs caught every month is indicated.

Datos sobre el ciclo de vida de Epeorus sylvicola/E. torrentium (ver texto): A) Datos conjuntos de las estaciones de muestreo del Río Aguas Blancas, B) Datos conjuntos de las estaciones de muestreo IV-VIII. Las flechas indican capturas de adultos. La media de la evolución mensual de la temperatura se representa por una línea continua. Se indica el número de ninfas capturadas cada mes.

cluded that most of the population of E. torrentium had a univoltine development while a small part was univoltine.

According to captures of fully-grown nymphs and adults, at sampling stations IV-VIII (fig. 8 B), the emergence period of subimagines occurs from the beginning of May to August. Hatching begins in summer, and increases during summer, so it is possible to find half-grown nymphs in autumn. Hatching continues at intervals during the winter. In late autumn and at the beginning of winter the growth is slow, but it increased in March in accordance with a temperature increase, so that in late spring, fully-grown nymphs appeared and subimagines began to emerge. In Río Aguas Blancas a similar development occur (fig. 8 A).

\section{ACKNOWLEDGEMENTS}

We are most grateful to Professor F. Jiménez Millán for valuable advice and comments, to Marichu, who assisted considerably with the field work and graphics, and to Mrs. C. Walhead of the British Council in Granada for checking the English.

This work has been supported by a grant from the Spanish «Comisión Asesora de Investigación Científica y Técnica» (CAICYT 3243183) to the Department of Zoology, University of Granada. 


\section{RESUMEN}

\section{CICLOS DE DESARROLLO Y ECOLOGÍA DE EFEMERÓPTEROS DE SIERRA NEVADA (ESPAÑA), IV.}

Como resultado de un muestreo mensual realizado a lo largo de un ciclo anual en seis cursos de agua de Sierra Nevada (sur de España), se presentan aquí los resultados relativos a los ciclos de desarrollo y autoecología de las siguientes especies de efemerópteros: Ephemerella ignita (Poda, 1761), Ephemera danica (Müller, 1764), Caenis luctuosa (Bürmeister, 1839) y Epeorus sylvicola (Pictet, 1865)/E. torrentium (Eaton, 1881).

Se capturaron ninfas de E. ignita en todas las estaciones de muestreo, con una densidad poblacional media máxima de 180 ninfas $/ \mathrm{m}^{2}$. Habitan preferentemente en las zonas de orilla provistas de abundante vegetación, con diferentes tipos de substratos y velocidades de corriente en el fondo, desde prácticamente nulas hasta de $108+9$ $\mathrm{cm} / \mathbf{s}$. Esta especie presentó en la mayoría de las estaciones de muestreo un ciclo de tipo univoltino con emergencias de subimagos de finales de junio a agosto; se observó la presencia de ninfas pequeñas a finales de julio y a comienzos de septiembre, y se considera posible en algunas estaciones de muestreo la hipótesis, sugerida anteriormente por vanos autores, de la existencia de una segunda generación que no sobrevive al invierno.

Las ninfas de $\boldsymbol{E}$. danica se capturaron en el Río Aguas Blancas, con una máxima densidad poblacional media en cabecera de 267 ninfaslm ${ }^{2}$. Habitan preferentemente en las zonas de orilla con fondos de arena y fangos con vegetación y detritus vegetales; con velocidades de corriente en el fondo desde prácticamente nulas hasta de $88 \pm 6$ $\mathbf{c m} / \mathbf{s}$. Parte de la población desarrolla un ciclo univoltino y la otra un ciclo semivoltino (de dos años de duración), con períodos de emergencia de subimagos desde junio hasta la primera mitad de agosto.

Las ninfas de Epeorus se capturaron en las zonas centrales del cauce con substratos pedregosos y velocidades de corriente en el fondo entre $45 \pm 8 \mathrm{~cm} / \mathrm{s}$ y $121 \pm 11 \mathrm{~cm} / \mathrm{s}$, pero preferentemente por encima de $60 \mathrm{cmis}$ y presentaron un ciclo univoltino con periodos de emergencia de subimagos desde comienzos de mayo hasta agosto.

\section{BIBLIOGRAPHY}

Alba-Tercedor, J., 1981. Efemerópteros de Sierra Nevada: Ciclos de Desarrollo, Taxonomía y Ecología de las Ninfas. Tesis doctoral, Universidad de Granada. $475 \mathrm{pp}$.

Alba-Tercedor, J., 1983. Ewlogía, distribución y ciclos de desarrollo de efemerópteros de Sierra Nevada, I: Baetis maurus Kimmins, 1938 (Ephemeroptera, Baetidae). In: N. Prat (ed.), Actas del Primer Congreso Español de Limnología: 179-182. Barcelona. 298 pp.

Alba-Tercedor, J., 1986. Ecología, distribución y ciclos de desarrollo de efemerópteros de Sierra Nevada (Granada, España). II: Baetidae Leach, 1815 (Insecta: Ephemeroptera). Limnetica 1(1): 234-246.

AlBA-TERCEDOR, J., 1990. Life cycles and ecology of some species of Ephemeroptera from Spain. In: I.C. Campbell (ed.), Mayflies and Stoneflies Life Histories and Biology, pág. 13-16. Klumer Academic Publ. (Series Entom-, Dr. W. Junk, 14). Dordrecht, Boston, London. 366 pp.

Alba-TerCEDOR, J. \& F. JiméNEZ-MiLlán, 1978. Larvas de efemerópteros de las estribaciones de Sierra Nevada. Factores que intervienen en su distribución. Bol. Asoc. esp. Entom. 2: 91-103.

Bass, J.A.B., 1976. Studies on Ephemerella ignita (Poda) in a chalk stream in southern England. Hydrobiologia 49: 117-121.

Berthelemy, C. \& A. Thomas, 1967. Note taxonomique sur Epeorus torrentium Eaton, 1881 et $\boldsymbol{E}$. assimilis Eaton, 1885 (Ephemeroptera, Heptageniidae), Annls Limnol. 3: 65-74.

BoHLE, H.W., 1972. Die Temperaturabhangigkeit der Embryogenese und der embryonalen Diapause von Ephemerella ignita (Poda) (Insecta, Epherneroptera). Oecologia 10: 253-268.
Clifford, H.F., 1982. Life cycles of mayflies (Ephemeroptera) with special reference to voltinism. Quaest. Entomol. 18: $15-89$

DelvauX, L., 1979. Spiriopsis adipophila (Arvy et Delage), 1966 parasite constant des populations d'Ephemera danica du Grand-Duché de Luxembourg. In: K. Pastemak \& R. Sowa (eds.), Proc. 2nd Int. Conference on Ephemeroptera: 221-223. Warsaw-Kraków. 312 pp.

Dorier, A. \& F. VAILlant, 1954. Observations et expériences relatives à la resistance au courant de divers invertébrés aquatiques. Trav. Lab. Hydrob. Pisc. Univ. Grenoble 45, 46: 9-31.

Dowdeswell, W.H., 1967. Practical Animal Ecology. Methuen Education Ltd. London. 320 pp.

ElliotT, J.M., 1967. The life-histories and drifting of the Plecoptera and Ephemeroptera in a Dartmoor stream. J. Anim. Ecol. 36: 343-362.

ELLIOTT, J.M., 1978. Effect of temperature on the hatching time eggs of Ephemerella ignita (Poda) (Epherneroptera: Ephemerellidae). Freshwat. Biol. 8: 51-58.

GraNDI, M., 1960. Ephemeroidea. Calderini. Bologna. 474 pp.

Guillouzic, M., 1965. Cycles de développement de quelques Éphéméroptères du Volp. D.E.S. Fac. Sc., Univ. Toulouse. France. 34 pp. (not seen, recorded by THIBAULt, 1971).

HaLford, F.M., 1889. Dry Fly Fishing, Theory and Practice. Barry Shurlock \& Co., Reading. (not seen, recorded by WHELAN, 1980).

HyNes, H.B.N., 1961. The invertebrate fauna of a Welsh mountain stream. Arch. Hydrobiol. 57: 344-348.

ILlies, J., 1952. Die Mölle. Faunistich okologische untersuchungen an einem Forellenbach im lipper Bergland. Arch. Hydrobiol. 46: 424-612. (not seen, recorded by Thibault, 1971). 
JAZDZEWSKA, T., 1971. Jetki (Epherneroptera) rzebi Grsbi Pol. Pismo ent. 41: 243-304.

JAZDZEWSKA, T., 1980. Structure et fonctionement des ecosystèmes du Haut-Rhône Français. 17. Le cycle vital d'Ephemerella ignita Poda 1761 (Ephemerellidae, Ephemeroptera) dans le Rhône Lyonnais. Bull. Ecol. 11: 33-43.

JENSEN, C.F., 1956. Ephemeroptera (Døgnfluer). In: Faunistisk biologisk undersøgelse of Skern A. Flora of Fauna 62: 53-75.

LaNDA, V., 1968. Developmental cycles of central European Ephemeroptera and their interrelations. Acta ent. bohemoslov, 65: 276-284.

MaCAN, T.T., 1970. A key to the nymphs of Bntish species of Ephemeroptera, with notes on their ecology. Freshwat. Biol. Ass. Scient. 20: 1-68.

MaCAN, T.T., 1979. A key to the nymphs of British species of Ephemeroptera. Freshwat. Biol. Ass. Scient. 20: 1-79.

PearT, A.R., 1916. Notes on the introduction and propagation of Ephemendae. Salmon Trout Mag. 14: 29-42.

Percival, E. \& H. Whitehead, 1928. Observations on the ova and ovoposition of certain Ephemeroptera and Plecoptera. Proc. Leeds Phil. Soc. 1: 271-288. (not seen, recorded by ElliotT, 1978 and Whelan, 1980).

Pleskot, G., 1959. Die Periodizität einiger Ephemeropteren der Schwechat. Gewässer und Abwüsser, 1958: 1-32.

Pleskot, G., 1961. Die Periodizitat der ephemeropteren Fauna einiger osterreichischer Fliessgewasser. Verh. int. Ver. Limnol. 14: 410-416.

Rosillon, D., 1986. Life cycles of four ephemeropteran species in a chaiky stream. Poisk. arch. hydrobiol. 33: 21-31.

SANDER, U., 1981. Faunistisch-ekologische Untersuchungen über die Ephemeroptera des südlichen Schwarzwaldes unter besonderer Beücksichtigung der Donauquellflüsse Breg und Brigach un der obersten Donauabschnittes bis Versi- cherung bei Immendigen. Arch. Hydrobiol. Suppl. 52: 409-461.

SowA, R., 1975a. Ecology and biogeography of mayflies (Epherneroptera) of running waters in the Polish part of the Carpathians. 1. Distribution and quantitative analysis. Acta Hydrobiol. 17: 223-297.

SowA, R., 1975b. Ecology and biogeography of mayflies (Ephemeroptera) of running waters in the Polish part of the Carpathians. 2. Life cycles. Acta Hydrobiol. 17(4): 319-353.

SvensSON, B., 1977. Life cycle, energy fluctuations and sexual differentiation in Ephemera danica (Ephemeroptera), a stream-living mayfly. Oikos 29: 78-85.

Thibault, M., 1969. Le développment des éphéméroptères semivoltins et univoltins d'un ruisseau du Pays Basque Français. Doctorat thèse. Univ. Paris. 78 pp. (not seen, recorded by Eluiotr, 1978)

THIBAULT, M., 1971. Le développment des éphéméroptères d'un ruisseau à truites des Pyrénées atlantiques. Le Lissuraga. Annls Limnol. 7: 53-120.

WHELAN, K.F., 1980. Some aspects of the biology of Ephemera danica Müll. (Ephemendae: Ephemeroptera). In: J.F. Flannagan \& K.E. Marshall (eds.), Advances in Ephemeroptera Biology: 115-121. New York \& London. 552 pp.

WISE, E.J., 1976. Studies on the Ephemeroptera of a Northumbriam river system, I. Serial distribution and relative abundance. Freshwater Biology 6: 363-372.

WISE, E.J., 1980. Seasonal distnbution and life histories of Ephemeroptera in a Northumbrian nver. Freshwater Biology 10: 101-111.

Wright, J.F., P.D. Hiley \& A.D. BerRie, 1981. A 9-year study of the life cycle of Ephemera danica (Ephemendae: Ephemeroptera) in the River Lambourn, England, U.K. Ecol. Entomol. 6: 321-332. 